\title{
Effect on soil health of cauliflower (Brassica oleracea var. botrytis) cultivation with Integrated Nutrient Management
}

\section{Rohit Pawar*}

Department of Vegetable Science, COH, Dr. Y.S Parmar University of Horticulture and Forestry, Nauni, Solan -173230 (Himachal Pradesh), India

\section{Santosh Barkule}

Department of Horticulture, Vasantrao Naik Marathwada Krishi Vidyapeeth, Parbhani - 431402 (Maharastra), India

Shruti Kirti

Department of Basic Sciences, $\mathrm{COH}$, Dr. Y.S Parmar University of Horticulture and Forestry, Nauni, Solan -173230 (Himachal Pradesh), India

\section{Dipesh Rasal}

Department of Seed Science and Technology, COH, Dr. Y.S Parmar University of Horticulture and Forestry, Nauni, Solan -173230 (Himachal Pradesh), India

*Corresponding author. E-mail: rohitpawar0099@gmail.com

\begin{abstract}
Brassica oleracea var. botrytis L. (Cauliflower) is an important commercial vegetable crop grown all over the world. In order to meet the growing demand of burgeoning population, large amounts of herbicides, pesticides and fertilizers are being applied to the fields every year to achieve maximum production leading to deleterious environmental effects. The present investigation 'Integrated nutrient management in cauliflower was undertaken at the Instructional Farm of Department of Horticulture, College of Agriculture, Latur during the Rabi season. The experiment laid out in Randomized Block Design (R.B.D.) with fourteen treatments replicated thrice. The treatment comprises with RDF (120:80:40 NPK kg/ ha.), FYM (10 t/ha), Azotobacter and Azospirillum (10 kg/ha). The variety Snowball - 16 was selected for the study. The data regarding soil analysis after harvesting, the maximum available nitrogen (265.66 kg ha-1), available phosphorus $\left(23.26 \mathrm{~kg} \mathrm{ha}^{-1}\right)$ and available potassium $\left(415.33 \mathrm{~kg} \mathrm{ha}^{-1}\right.$ ) were recorded in highest dose of INM i.e. $100 \%$ RDF + $\mathrm{FYM}+$ Azotobacter + Azospirillum $\left(\mathrm{T}_{2}\right)$ and is was statistically at par with $\mathrm{T}_{6}$ and $\mathrm{T}_{8}$. The maximum organic carbon (0.93 per cent) was recorded in the treatment $75 \%$ RDF + FYM + Azotobacter + Azospirillum $\left(\mathrm{T}_{6}\right)$. There were no significant differences of INM treatments observed on soil $\mathrm{pH}$ and electrical conductivity. This result suggested that $25 \%$ chemical fertilizers can be reduced without any compromise on fertility status of the soil for cauliflower crop production in sub-tropical condition.
\end{abstract}

Keywords: Bio-fertilizers, Cauliflower, Organic manures, Soil health, Synthetic fertilizers

\section{INTRODUCTION}

Vegetable plays an important role in human nutrition. These are an indispensable group of food, providing vitamins, minerals, protein, carbohydrates and fibers in the diet, besides having medicinal value and provide nutritional security. Among different vegetables, Brassica oleracea var. botrytis L. (cauliflower) is one of the most important winter vegetables among the Cole crops which belongs to the genus Brassica of the family Cruciferae. Cauliflower is essentially a cold weather hardy crop and thrives best in cool and moist climate. Cauliflower is the fifth most important vegetable crop in India, primarily grown in the winter season. In India cauliflower grown over an area 433.9 thousand ha with a production of

\section{Article Info}

DOI:10.31018/jans.v10i3.1881

Received: February 5, 2018

Revised: July 26, 2018

Accepted: August 22, 2018

\section{How to Cite}

Pawar, R. et al. (2018). Effect on soil health of cauliflower (Brassica oleracea var. botrytis) cultivation with Integrated Nutrient Management. Journal of Applied and Natural Science, 10(3): $1026-1031$ about 5873.3 thousand MT/ha and productivity is 19.8 MT/ha. The dramatic increase in vegetable production and the increase in fertilizer consumption point to the crucial role of fertilizers. In 2014 the highest area and production of cauliflower is in West Bengal ie.73.6 thousand ha, 1879.0 thousand MT/ha respectively (Anonymous, 2014).

The utilization of bio-fertilizers, which have a ability to enrich the soil with beneficial microorganisms as well as to mobilize the nutritionally important elements like $\mathrm{P}, \mathrm{K}$ and micronutrients like Zn, Mo (Mishra and Dash, 2014) from non-usable to usable forms through biological processes resulting in enhanced production of fruits and vegetables offer an alternative. The use of biofertilizers in combination with chemical fertilizers 
and organic manures offers a great opportunity to increase the production as well as the quality of cauliflower. Organic manure improves soil structure and water holding capacity, resulting in more extensive root development and enhanced soil micro flora and fauna activity, which results in availability of micronutrients available to plants (Damse et al., 2014).Shree et al. (2014) conducted an experiment in cauliflower with different combinations of five varied sources of nutrients including organic, inorganic and bio-fertilizers. The application of $1 / 2 \mathrm{~N}$ : P: K (recommended dose) + FYM @ 5 t/ha + poultry manure @ 2 t/ha + Azospirillum was found to be the most effective treatment combination for getting enhanced yield and quality. Kumar and Devi (2016) laid out an experiment with combination of inorganic, organic and bio-fertilizers and suggested that plant nutrient sources including farmyard manure, bio fertilizers and synthetic fertilizers had significant effect on yield and quality of cauliflower. Bio-fertilizers can symbiotically associate with plant roots. Involved microorganisms could readily and safely convert the complex organic material into simple compounds, so that they took up by the plants. Microorganism function is in long duration, causing important of the soil fertility. It maintains the natural habitat of the soil. It increases crops yield by $20-30 \%$, replaces chemical nitrogen and phosphorus by $25 \%$ and stimulates plant growth (Gupta et al., 2015). It can also provide protection against drought and some soil-borne diseases (Purkayastha et al., 1998). Among the nitrogen fixing bacteria, Azotobacter, not only provides nitrogen, but also synthesizes growth promoting hormones such as IAA and GA. Azospirillum also helps in plant growth and increases the yield of crops by improving root development, mineral uptake etc. The positive role of these bio-fertilizers has been recorded in many vegetables and spice crops by different scientists. To maintain long term soil health and productivity there is a need for integrated nutrient management through manures and bio-fertilizers apart from costly chemical fertilizers for better yield of the crop (Mondal et al., 2003).

Cauliflower is being grown round the year for its white and tender curd. It is widely cultivated all over the world for its special nutritive values, high productivity and wider adaptability under different ecological conditions. The cauliflower crop of Brassica family is a heavy feeder of mineral elements; it removes a large amount of macronutrients from the soiland for that Heavy manuring has been recommended for getting a good yield of cauliflower by different workers in India (Pawar and Barkule, 2017). Mineral nutrition does play an important role in influencing the quality of crops and it is fact that the soil health deteriorates due to continuous use of chemical fertilizers, (Savci,
2012). The integrated nutrient management paves the way to overcome these problems, which involves the conjunctive use of chemical fertilizers and organic manures to sustain crop production as well as maintenance of soil health (Nanjappa et al., 2001).A systematic approach to nutrient management by tapping all possible sources of organic and inorganic in a judicious manner to maintain soil fertility and crop productivity is the essence of integrated nutrient management (INM). Therefore, the present investigation was undertaken to study the effect of inorganic fertilizers alone and in combination with different bio-fertilizers on soil healthof cauliflower production in sub-tropical condition.

\section{MATERIALS AND METHODS}

The present investigation on the effect of integrated nutrient management on growth and yield of cauliflower (Brassica oleracea var. botrytis L.) was carried out at Vegetable Research Farm of Department of Horticulture, College of Agriculture, Latur, under Vasantrao Naik MarathwadaKrishiVidyapeeth, Parbhani, Maharashtra. The experiment was laid out in randomized block design with three replications comprising of fourteen treatment combinations (Table 1). For mechanical analysis we uselnternation pipette method (piper, 1966) and for chemical analysis we use different methods like Soil $\mathrm{pH}(1: 2.5)$ by Digital $\mathrm{pH}$ Meter (Jackson, 1973), Organic carbon (\%) by Rapid Titration method (Walkley and Black, 1934), Available $\mathrm{N}(\mathrm{Kg} / \mathrm{ha})$ by Alkaline Potassium Permanganate Method (Subbiah and Asija 1956), Available P (kg/ha) by Olsen Methods (Olsen et al., 1954) and Available K (kg/ha) by Normal Natural Ammonium Acetate Method (Merwin and peech, 1951). The seeds were sown in raised nursery beds. After sowing, seeds were covered with a thin film of soil mixed with Farm Yard Manure. Thereafter, paddy straws mulching was incorporated to reduce moisture loss. The beds were irrigated twice a day with the help of water can maintain optimum moisture in the soil.

Before laying out the experiment, a random soil sample was collected from the furrow slice (0-15 $\mathrm{cm}$ depth) of different spots and a composite sample was prepared for determination of various soil characters (Table 2).

Healthy seedlings were used for transplanting in the main field. The required quantity of biofertilizers such as Azotobactor and Azospirillum (10 kg/ha) was mixed in soil and given to the respective plots. The FYM (10 t/ha) and RDF (N:P:K; 120:80:40 kg/ha) were applied as per the decided treatments in which half dose of nitrogen through urea along with the full dose of phosphorous through single super phosphate and potassium through murate of potash was applied. The half dose of nitrogen was given as per treatments 
after 30 days of transplanting. Healthy uniform seedlings of four weeks age were selected for transplanting and they were treated with bavistin @ $2 \mathrm{~g}$ /lit and transplanted in the plot size $3.6 \mathrm{~m} \mathrm{x}$ $2.7 \mathrm{~m}$ at a spacing of $60 \times 45 \mathrm{~cm}$. Thus, the numbers of plants per plot were 36 . Light irrigation was given immediately after transplanting. The standard cultural practices as in Package of Practices for Vegetable Crops were followed from time to time to ensure a healthy crop stand (Anonymous, 2009)

The observations were recorded for soil health characters viz., available nitrogen ( $\mathrm{kg} / \mathrm{ha}$ ), available phosphorus $(\mathrm{kg} / \mathrm{ha})$, available potassium $(\mathrm{kg} /$ ha), soil $\mathrm{pH}$, Soil electric conductivity $(\mathrm{dS} / \mathrm{m})$ and soil organic carbon (\%). After the completion of the experiment, the sample from different plots was taken and analysed for available nutrient elements by following the standard methods as mention above.

The experimental data of all the parameters was subjected to statistical analysis for proper interpretation. The statistical analysis of data in respect of the growth and yield components was done according to the standard procedure given for randomized block design by Panse and Sukhatme (1967).

\section{RESULTS AND DISCUSSION}

Soil analysis: The data regarding initial soil analysis and after harvesting of cauliflower as influenced by different treatments of INM are presented in Table 3.

Available Nitrogen: The data showed that, the maximum available nitrogen (265.66 kg ha-1) was recorded in the treatment of $100 \%$ RDF+ FYM + Azotobacter + Azospirillum $\left(\mathrm{T}_{2}\right)$ and it was statistically at par with treatments $\mathrm{T}_{6}, \mathrm{~T}_{4}$ and $\mathrm{T}_{8}$. The lowest level of available nitrogen (168.26 kg ha-1) was recorded in treatment control $\left(\mathrm{T}_{14}\right)$. Biodegradation process of organic manurewas carried out by different groups of heterotrophic microorganisms, bacteria, fungi, actinomycetes and protozoa, the population of which depending upon the carbona- ceous and release of nutrient in plant available forms were dependent upon the $\mathrm{C}$ : $\mathrm{N}$ ratio. The $\mathrm{C}$ : $\mathrm{N}$ ratio of $\mathrm{FYM}$ and bio-fertilizer were 16.00 and 10.0-12.3 respectively, which stand above the ideal 10: 1 ratio. Available nitrogen can be increased by the addition of nitrogenous fertilizer and biofertilizers to the manures thereby, reducing the $\mathrm{C}$ : $\mathrm{N}$ ratio. The result obtained on the beneficial effect of inorganic fertilizers, organic manure and biofertilizers were in collaboration with the findings of Stevenson (1982) in cauliflower and Ganesh et al. (2011) in rice. The present finding is in line with those of Dass et al. (2000), Sarang them et al.(2011) and Kumar (2014) in cauliflower, cabbage and sprouting broccoli, respectively.

Available phosphorus and potassium: Regarding the available phosphorus, there were significant differences in all the treatments studied. The Maximum phosphorus content $\left(23.26 \mathrm{~kg} \mathrm{ha}^{-1}\right)$ has been obtained in the treatment of $100 \%$ RDF+ $\mathrm{FYM}+$ Azotobacter + Azospirillum $\left(\mathrm{T}_{2}\right)$ and it was at par with the treatment $T_{6}$. The least available phosphorus $\left(9.12 \mathrm{~kg} \mathrm{ha}^{-1}\right)$ was recorded in thetreatment control $\left(T_{14}\right)$. On other hand the data on available potassium in the soil showed significant differences with all treatments. The maximum level of available potassium (415.33 kg ha-1) was observed in the treatment of $100 \%$ RDF+ FYM + Azotobacter + Azospirillum $\left(\mathrm{T}_{2}\right)$, which was significantly superior to rest of treatment. The lowest available potassium $\left(281.87 \mathrm{~kg} \mathrm{ha}^{-1}\right)$ was recorded in the treatment control $\left(T_{14}\right)$. This was due to physico-chemical release of inorganic and organic phosphorus by organic acids through the action of thelow molecular weight of organic anions such as oxalate which can replace phosphorus absorbed at metal hydroxide surfaces through legend exchange reactions and dissolve metal oxide surfaces that absorb phosphorus. The application of biofertilizers could be a higher number of $\mathrm{N}, \mathrm{P}$ and $\mathrm{K}$ content were significantly increased by the bacteria present under inoculated conditions. The result obtained collaborated with the reports of Ganesh

Table 1. Treatment details for cauliflower crop and their symbols.

\begin{tabular}{lll}
\hline Sr. No. & Treatments details & Symbol \\
\hline 1 & $100 \%$ RDF (120:80:40 kg/ha.) & $\mathrm{T}_{1}$ \\
2 & $100 \%$ RDF+ FYM + Azotobacter + Azospirillum & $\mathrm{T}_{2}$ \\
3 & $100 \%$ RDF + Azotobacter + Azospirillum & $\mathrm{T}_{3}$ \\
4 & $100 \%$ RDF + FYM + Azotobacter & $\mathrm{T}_{4}$ \\
5 & $100 \%$ RDF+ FYM + Azospirillum & $\mathrm{T}_{5}$ \\
6 & $75 \%$ RDF + FYM + Azotobacter + Azospirillum & $\mathrm{T}_{6}$ \\
7 & $75 \%$ RDF + Azotobacter + Azospirillum & $\mathrm{T}_{7}$ \\
8 & $75 \%$ RDF+ FYM + Azotobacter & $\mathrm{T}_{8}$ \\
9 & $75 \%$ RDF+ FYM + Azospirillum & $\mathrm{T}_{9}$ \\
10 & $50 \%$ RDF+ FYM + Azotobacter + Azospirillum & $\mathrm{T}_{10}$ \\
11 & $50 \%$ RDF+ FYM + Azotobacter & $\mathrm{T}_{11}$ \\
12 & $50 \%$ RDF + FYM + Azospirillum & $\mathrm{T}_{12}$ \\
13 & $50 \%$ RDF + Azotobacter + Azospirillum & $\mathrm{T}_{13}$ \\
14 & Control & $\mathrm{T}_{14}$ \\
\hline \hline
\end{tabular}


Pawar, R. et al. / J. Appl. \& Nat. Sci. 10 (3): 1026 -1031 (2018)

Table2. Physico-chemical properties of soil before transplanting of cauliflower crop.

\begin{tabular}{llll}
\hline Particulars & $\begin{array}{l}\text { Value } \\
\text { tained }\end{array}$ & ob- & Method Employed \\
\hline Mechanical analysis & & \\
\hline 1. Sand & 39.27 & \\
2. Slit & 32.10 & International pipette method (piper, 1966) \\
3. Clay & 27.30 & \\
\hline Chemical analysis & & \\
\hline Soil pH (1: 2.5) & 7.97 & Digital pH Meter (Jackson, 1973) \\
Organic carbon (\%) & 0.50 & Rapid Titration method (Walkley and Black, 1934) \\
Available N (Kg/ha) & 177.45 & Alkaline Potassium Permanganate Method ( Subbiah and Asija 1956) \\
Available P (kg/ha) & 9.17 & Olsen Methods (Olsen et al., 1954) \\
Available K (kg/ha) & 293.00 & Normal Natural Ammonium Acetate Method (Merwin and peech, 1951) \\
\hline
\end{tabular}

Table 3. Effect of different INM treatments on soil nutrient status for cauliflower crop.

\begin{tabular}{|c|c|c|c|c|c|c|c|}
\hline \multirow{2}{*}{$\begin{array}{l}\text { Tr. } \\
\text { No. }\end{array}$} & Treatments & $\begin{array}{c}N \\
\text { (kg/ha) }\end{array}$ & $\begin{array}{c}P \\
\text { (kg/ha) }\end{array}$ & $\begin{array}{c}\mathrm{K} \\
(\mathrm{kg} / \mathrm{ha}) \\
\end{array}$ & $\mathbf{P}^{\mathrm{H}}$ & $\begin{array}{c}E C \\
(\mathrm{dS} / \mathrm{m})\end{array}$ & $\begin{array}{l}\text { OC } \\
(\%)\end{array}$ \\
\hline & Initial values & 177.45 & 9.17 & 293.00 & 7.97 & 0.49 & 0.50 \\
\hline $\mathrm{T}_{1}$ & 100 \% RDF (120:80:40kg/ha.) & 227.66 & 15.30 & 312.33 & 8.21 & 0.51 & 0.46 \\
\hline $\mathrm{T}_{2}$ & $100 \% \mathrm{RDF}+\mathrm{FYM}+A b .+A p$ & 265.66 & 23.26 & 415.33 & 7.80 & 0.48 & 0.82 \\
\hline $\mathrm{T}_{3}$ & $100 \% \mathrm{RDF}+A b .+A p$ & 243.00 & 14.33 & 354.33 & 8.20 & 0.47 & 0.51 \\
\hline $\mathrm{T}_{4}$ & $100 \% \mathrm{RDF}+\mathrm{FYM}+A b$ & 255.00 & 17.66 & 390.00 & 7.80 & 0.43 & 0.66 \\
\hline $\mathrm{T}_{5}$ & $100 \%$ RDF+FYM + Ap. & 242.00 & 11.21 & 340.20 & 7.86 & 0.45 & 0.56 \\
\hline $\mathrm{T}_{6}$ & $75 \% \mathrm{RDF}+\mathrm{FYM}+A b .+A p$ & 259.00 & 22.03 & 383.00 & 7.68 & 0.46 & 0.93 \\
\hline $\mathrm{T}_{7}$ & $75 \% \mathrm{RDF}+A b .+A p$ & 245.33 & 15.60 & 330.00 & 8.20 & 0.42 & 0.56 \\
\hline $\mathrm{T}_{8}$ & $75 \%$ RDF+FYM + Ab. & 250.00 & 18.66 & 382.00 & 7.80 & 0.41 & 0.89 \\
\hline $\mathrm{T}_{9}$ & $75 \%$ RDF+FYM + Ap. & 251.66 & 12.66 & 320.05 & 7.80 & 0.45 & 0.88 \\
\hline $\mathrm{T}_{10}$ & $50 \%$ RDF+FYM+Ab. $+A p$ & 201.33 & 16.66 & 347.00 & 7.80 & 0.41 & 0.77 \\
\hline $\mathrm{T}_{11}$ & $50 \% \mathrm{RDF}+\mathrm{FYM}+A b$ & 241.66 & 13.55 & 322.00 & 7.80 & 0.47 & 0.69 \\
\hline $\mathrm{T}_{12}$ & $50 \% \mathrm{RDF}+\mathrm{FYM}+A p$ & 236.66 & 15.69 & 309.05 & 8.20 & 0.43 & 0.55 \\
\hline $\mathrm{T}_{13}$ & $50 \% \mathrm{RDF}+A b .+A p$ & 221.00 & 15.23 & 300.00 & 8.20 & 0.40 & 0.43 \\
\hline \multirow[t]{3}{*}{$\mathrm{T}_{14}$} & Control. & 168.26 & 9.12 & 281.87 & 7.96 & 0.46 & 0.38 \\
\hline & S.E. \pm & 4.62 & 0.72 & 5.41 & 0.17 & 0.02 & 0.021 \\
\hline & C.D. at $5 \%$ & 14.09 & 2.21 & 16.51 & NS & NS & 0.065 \\
\hline
\end{tabular}

et al. (2011) and Selvakumar et al. (2012). The similar results have alsobeen reported by Chander et al. (2010), Tekasangla et al. (2015) and Kumar and Devi (2016) in cole crop.

Soil $\mathrm{pH}$ and electrical conductivity: The data clearly indicated that, No significant differences were observed with respect to $\mathrm{pH}$ and $\mathrm{EC}$ of soil by different treatments. However, the treatment of $100 \% \operatorname{RDF}\left(\mathrm{T}_{1}\right)$ has recorded highest $\mathrm{pH}(8.21)$ and the treatment of $100 \% \mathrm{RDF}+\mathrm{FYM}+$ Azotobacter + Azospirillum $\left(\mathrm{T}_{2}\right)$ has recorded highest EC $(0.51 \mathrm{dS} / \mathrm{m})$ which was followed by $T_{1}$ and $T_{3} .$. The lowest $\mathrm{pH}$ (7.68) was recorded in treatment of $75 \%$ RDF+ FYM + Azotobacter + Azospirillum $\left(\mathrm{T}_{6}\right)$. The lowest EC $(0.40 \mathrm{dS} / \mathrm{m})$ was recorded in treatment of $50 \%$ RDF + Azotobacter + Azospirillum $\left(\mathrm{T}_{13}\right)$. The measure of soil reaction with respect to the $\mathrm{pH}$ and electrical conductivity of the soil showed no significant differences due to the levels and combination of inorganic fertilizers, organic manureandbio-fertilizers. The application of various organic materials decreased the $\mathrm{pH}$ and EC values, which was due to organic and inorganic acids formation during organic matter decomposition. The soil treated with organic manures and bio-fertilizers could be the reason for the acidifying effect of organic acid produced upon decomposition. The results obtained were in conformity with the findings of Prakash et al. (2002) and Stevenson (1982). This decline in soil pH may be ascribed to the formation of organic acids due to the decomposition of organic manure and crop residues (Sharma et al., 2013)

Soil organic carbon: As regards to the organic carbon, there were significant differences observed in all the treatment studied. The maximum organic carbon recorded $(0.93 \%)$ in the treatment of $75 \%$ RDF + FYM + Azotobacter + Azospirillum $\left(T_{6}\right)$ followed by the treatments $T_{8}$ and $T_{9}$ which were statistically at par. The lowest organic carbon $(0.38 \%)$ was recorded in treatment control $\left(T_{14}\right)$. The cause associated with such a trend of results could be due to the high organic carbon status of manures used in the study. The results were in accordance with findings of Prakash et al. (2002) who opinioned that application of organic manure increased the CEC and organic carbon content and decreased the bulk density of soil.

\section{Conclusion}

It is concluded from the present study, the use of integrated plant nutrient sources including synthetic fertilizers, organic manure and bio-fertilizers had a significant effect on increasing soil health for 
cauliflower production. The treatment of $75 \%$ RDF + FYM @ 10t/ha + Azotobacter @ 10 kg/ha + Azospirillum @10 kg/ha was prove to be the optimum combination of inorganic and bio-fertilizer for maintaining soil health. Resource-poor farmers who are unable to apply a full dose of recommended fertilizer may apply $75 \%$ of recommended dose of fertilizers along with bio-fertilizers in a balanced way to improve soil health of field and almost save the 25 per cent of the cost of fertilizers. The conformity of the experimental findings needs further investigation for second year to arrive at a valid conclusion. To maintain long term soil health and productivity, there is a need for integrated nutrient management through manures and bio-fertilizers apart from costly chemical fertilizers for better yield of the cauliflower crop.

\section{ACKNOWLEDGEMENTS}

The authors are thankful to The Head, Department of Horticulture, College of Agriculture, Latur, under Vasantrao Naik Marathwada Krishi Vidyapeeth Parbhani, Maharashtra India-431402 for the facilities provided during the experiment.

\section{REFERENCES}

1. Anonymous. (2009). Package of Practices for Vegetable Crop. Directorate of Extension Education, Dr Y S Parmar Universityof Horticulture and Forestry, Nauni, Solan. pp. 70-74.

2. Anonymous. (2014). Indian Horticulture Database, National Horticulture Board, Govt. of India retrieved from http://www.nhb.gov.in.

3. Chander G, Verma T.S. and Sharma S. (2010). Nutrient content of cauliflower Brassica oleracea L. var. botrytis) as influenced by boron and farmyard manure in northwest Himalayan alfisols. Journal of the Indian Society of Soil Science, 58:248-51.

4. Damse, D.N., Bhalekar, M.N and Pawar, P.K. (2014). Effect of integrated nutrient management on growth and yield of garlic. The Bioscan, 9(4): 1557-60.

5. Dass J, Pookan D.B. and Gautam B.P. (2000). Effect of level of NPK and Plant densities for curd production of early cauliflower (Brassica oleracea L. var. botrytis) cv. Pusakatki. Haryana Journal of Horticultural Sciences, 29:265-66.

6. Ganesh, P., Tharamraj, K., Kolanjinathan, K., (2011). Effect of inorganic manure and bio- fertilizers on physical, biological properties and growth of rice by application study. International $\mathrm{J}$. of Current Life Sci., 1 (1):11-15.

7. Gupta, S., Kaushal, R., Kaundal, K., Chauhan, A., And Spehia, R.S., (2015). Efficacy of indigenous plant growth promoting rhizobacteria on capsicum yield and soil health. Res. on Crops.16 (1): 123-132.

8. Jackson, M.L. (1973). Soil chemical analysis. $2^{\text {nd }}$, Prentice Hall of India Pvt. Ltd., New Delhi., 370-387.

9. Kumar P. (2014). Comparative efficiency of organic, inorganic and integrated nutrient management on growth, yield and quality of sprouting broccoli (Brassica oleracea L. var. italica) cv. Green head. Ph.D Thesis. Department of Vegetable Science, Dr YS Parmar University of Horticulture and Forestry, Nauni, Solan (HP). 72-84pp.
10.Kumar $V$ and Devi S. (2016). Effect of bio-fertilizers and inorganic amendments on mineralcomposition and quality of Brassica oleracea. Asian Journal of Advance Basic Science 4:20-26.

11.Merwin, H.D.andPeech, M., (1951). Exchangeability of soil potassium in the slit and clay fractions as influenced by the nature of the complimentary exchange cations. Soil Science Society of American Proceedings. 15, 125-128.

12.Mishra, P. and Dash, D. (2014). Rejuvenation of biofertilizer for sustainable agriculture and economic development. JSD.11(1), 41-61.

13.Mondal, T.,Ghanti, P.,Mahato, B., Mondal, A.R. and Thapa, U., (2003). Effect of spacing and bio-fertilizer on yield and yield attributes of direct sown Chilli ( $C$. annuum L. Cv Bona Lanka). Env. Eco. 21, 712-15.

14.Nanjappa, H.P, Ramchanrappa, B.K. and Mallikarjuna, B.O. (2001). Effect of integrated nutrient management on yield and nutrient balance in maize. Indian $\mathrm{J}$. Agron.46(4), 668-701.

15.Olsen, S.R, cole, C.V.Wantanwbe, F.S. and Dean, L.A. (1954). Estimation of available phosphorus in soil by extraction with $\mathrm{NaHCO}_{3}$. Cir.U.S.Deptt. Agric. 939.

16.Panse, V.G. and Sukhatme, P.V., (1967). Statistical method of agricultural workers.Published by I.C.A.R., New Delhi.

17.Pawar R. and Barkule S. (2017). Study on effect of integrated nutrient management on growth and yield of cauliflower (Brassica oleracea var. botrytis L.) J. Applied and Natural Sci. 9 (1): 520 - 525

18.Piper, C.S., (1966). Soil and plant analysis. Academic press. New York. 366.

19.Prakash, V.S., Bhandoria, P.B. and Amitava, R., (2002). Comparative efficiency of organicmanure on some physical and chemical properties of red loam soil under multiple cropping. J. Indian soc. Soil. Sci. 31: 601.

20.Purkayastha, T.J., Singh, C.S. and Chhonkar, P.K., (1998). Growth and iron nutrient of broccoli grown in a typicustochrept as influenced by VAM fungi in presence of pyrite and farmyard manure. Biol. Fert. Soil. 27(1): 45-48.

21.Sarangthem I, Mishra A.D and Chakraborty Y. (2011). Cabbage productivity, nutrient upake and soil fertility as affected by organic and bio-sources. Agricultural Science Digest., 31:260-64.

22.Savci, S., (2012). An agricultural pollutant: chemical fertilizer.IJESD. 3(1): 77-80.

23.Selvakumar, G., Reetha, S. and Thamizhiniyan, P., (2012). Responces of bio-fertilizers on growth, yield and Associated protein profiling changes of black gram (Vigna mungo L Hepper). World Applied Science J. 16 (10): 1368-1374.

24.Sharma, G.D., Thakur, R, RAJ, S, Kauraw, D.L., and Kulhare, P.S. (2013). Impact of integrated nutrient management on yield, nutrient uptake, protein content of wheat (Triticumastivam) and soil fertility in a typic haplustert. The Bioscan, 8(4): 1150-64.

25.Shree S, Singh V.K and Kumar R. (2014). Effect of integrated nutrient management on yield and quality of cauliflower (Brassica oleracea var. botrytis L.). The Bioscan, 9:1053-58.

26.Stevenson, F.J., (1982). Humus Chemistry; genesis; composition; reaction. Wiley-inter science, New York.

27.Subbiah, B.V. and Asija, G.L., (1956). A rapid procedure for the estimation of available nitrogen in soil. 
Pawar, R. et al. / J. Appl. \& Nat. Sci. 10 (3): 1026 -1031 (2018)

Curr. Sci., 25(8), 259-260

28.Tekasangla S.P, Kanaujia And Singh P.K. (2015). Integrated nutrient management for quality production of cauliflower in acid alfisol of Nagaland. Journal of the Indian Society of Soil Science 62:9-17.

29. Walkley, A. and Black, T.A., (1934). An experiment of vegetative modification of the chromic acid filtration method. Soil Science. 37, 38-39. 